[Agr. Biol. Chem., Vol. 33, No. 1, p. 31 35, 1969]

\title{
Studies on Hormonal Effects on Hepatic Histidase and Alanine Transaminase of Rats Fed on Either Histidine Controlled or Imbalanced Diet
}

\author{
By Katuhiko Noda and Akira YoshidA \\ Department of Nutrition, School of Medicine, Tokushima University \\ Received May 6, 1968
}

\begin{abstract}
Effects of several hormones on liver histidase activity were investigated to study the mechanism of elevation of the activity of histidase when rats were fed on a histidine imbalanced diet.

Continuous injection of thyroxine $(5 \sim 10 \mu \mathrm{g} / \mathrm{rat} / \mathrm{clay})$ diminished histidase activity, and hypophysectomy increased histidase activity as compared with that of non treated animals. No change was observed on alanine transaminase (GPT) by above treatments.

Neither histamine, insulin, triamcinolone, adrenaline, nor adrenalectomy affected on the activity of histidase. Injection of histidine to rats fed on a histidine imbalanced diet made the activities of histidase and GPT tend to decrease.
\end{abstract}

In the preceding papers, ${ }^{1,2)}$ the authors reported that the liver histidase activity was increased when rats were fed with some amino acid imbalanced diets. This increase of the enzyme was especially significant on a histidine imbalanced diet which contained a low level of casein supplemented with essential amino acid mixture lacking histidine. To study the mechanisms of the elevation of the enzyme activity by the amino acid imbalanced diets, the effect of several hormones on histidase and alanine transaminase, as reference, was investigated previously. ${ }^{31}$ As the further extention of the study, present paper reports the depressing effect of thyroxine on histidase activity although histamin, insulin, triamcinolone, adrenaline, or adrenalectomy had no effect.

1) K. Noda, Y. Kusaka and A. Yoshida, Agr. Biol. Chem., 31 (2), 217 (1967).

2) K. Noda and A. Yoshida, ibid, preceding report.

3) K. Noda and A. Yoshida, Tokushima J. Expl. Med., 14 (1, 2), 33 (1967).

\section{MATERIALS AND METHODS}

Animals and diets. Young male rats of Wistar strain were fed on a controlled or histidine imbalanced diet. Histidine imbalanced diet contained $50^{\circ}$ casein supplemented with $6.5 \%$ of an essential amino acid mixture lacking histidine as described in the previous report.1 Diets and water were given ad libitum. Each group contained 5 animals.

Operation of rats. Adrenalectomy and hypophysectomy were performed by the authors under anesthesia of sodium pentbarbtal solution. All operations were done according to the rutine methods, ${ }^{4,51}$ and after the operation, rats were kept on stock diet for a few days, then fed on the experimental diets. Drinking water of adrenalectomized rats contained $0.9 \%$ of $\mathrm{NaCl}$. The completeness of the operations was secured by autopsy at the end of the experimental period.

Hormones and chemicals. All drugs were injected subcutaneously. The amounts and the procedures of

4) "Hypophysis" ed. by Y. Ito, Ishiyaku Pub. 1955 , p. 148.

5) "Experimental Manuals for Animals" ed. by Y. Koyama and H. Fujii, Kyodo Isho Pub. Co., 1964, p. 106,112 . 
injection were as follows; (I) $1 \mathrm{mg}$ of histamine per rat in $12 \mathrm{hr}$ interval, throughout the experiment; (II) $25 \mathrm{mg}$ of histidine daily per rat per day; (III) protamin zinc insulin (PZI) daily one unit per rat per day; (IV) 0.4 or $1.0 \mathrm{mg}$ of triamcinolone acetanide solution per rat per day, only in the first two days of the experimental period; (V) $10 \mu \mathrm{g}$ of thyroxine-Na per rat per day to a control group and $5 \mu \mathrm{g}$ per rat per day to the group on histidine imbalanced diet; (VI) $0.05 \mathrm{mg}$ of adrenalin- $\mathrm{Cl}$ per rat per day. Thyroxine, histamine, and histidine were dissolved in $0.90 \% \mathrm{NaCl}$ solution. $\mathrm{PZI}$, adrenalin, and triamcinolone were obtained as solution. Duration of the experimental period was one to two weeks. At the end of the experimental period, liver histidase ${ }^{21}$ and $\mathrm{GPT}^{3}$ activities were measured.

\section{RESULTS}

\section{Effects of histidine or histamine}

Since the supplementation of $0.4 \%$ histidine to the histidine imbalanced diet decreased the activities of histidase and GPT, ${ }^{21}$ effects of the injection of histidine to rats fed on the histidine imbalanced diet were tested. The results are indicated in Table I. The injection of histidine to a controlled diet group decreased the growth rate of young rats and increased the activity of GPT slightly, but did not affect the activity of histidase as compared with those of the control group. Growth rate of rats was improved by injection of histidine on imbalanced diet group and both enzyme activities also showed the diminished tendencies as expected from the previous feeding results. ${ }^{2}$ Injection of histamine to test the effect of one of the histidine metabolites, did not affect on both growth and enzymes (Table II).

Effects of PZI, triamcinolone, adrenaline, and adrenalectomy

Administration of PZI prevented the initial weight loss of rats caused by feeding with the

TABLE I. EFFECTS OF HISTIDINE INJECTION ON WEIGHT GAIN AND THE ACTIVITIES of Liver Histidase AND GPT OF RATS FED ON EITHER Histidine CONTROLLED OR IMBalanCED DieT

\begin{tabular}{|c|c|c|c|c|c|c|c|}
\hline \multirow[b]{2}{*}{ Diet } & \multicolumn{4}{|c|}{ Exp. 1} & \multicolumn{3}{|c|}{ Exp. 2} \\
\hline & & $\begin{array}{c}\text { Weight gain } \\
\text { (g/week) }\end{array}$ & $\begin{array}{c}\text { Histidase } \\
\text { (mg urocanate } / g \\
\text { liver } / \mathrm{hr} \text { ) }\end{array}$ & $\begin{array}{c}\text { GPT } \\
\left(\mathrm{mg}_{\mathrm{fiver} / \mathrm{hr})} \mathrm{pyruvate} / \mathrm{g}\right.\end{array}$ & $\begin{array}{c}\text { Weight gain } \\
\text { (g/week) }\end{array}$ & $\begin{array}{c}\text { Histidase } \\
(\mathrm{mg} \text { urocanate } / \mathrm{g} \\
\text { liver } / \mathrm{hr})\end{array}$ & $\begin{array}{c}\text { GPT } \\
(\mathrm{mg} \mathrm{pyruvate} / \mathrm{g} \\
\text { liver } / \mathrm{hr})\end{array}$ \\
\hline Controlled & $\overline{\mathrm{His}}$ & 3.2 & $0.32 \pm 0.04$ & $81 \pm 5$ & $\begin{array}{l}5.5 \\
3.6\end{array}$ & $\begin{array}{l}0.50 \pm 0.08 \\
0.54 \pm 0.05\end{array}$ & $\begin{array}{l}60 \pm 10 \\
84 \pm 24\end{array}$ \\
\hline Imbalanced & $\overline{\mathrm{His}}$ & $\begin{array}{l}0.6 \\
5.2\end{array}$ & $\begin{array}{l}0.56 \pm 0.04 \\
0.45 \pm 0.09\end{array}$ & $\begin{array}{l}326 \pm 30 \\
239 \pm 115\end{array}$ & -1.5 & $0.77 \pm 0.07$ & $156 \pm 12$ \\
\hline
\end{tabular}

TABLE II. EFFECTS OF Histamin INJECTION ON WEIGHT GaIN AND Histidase and GPT Activities of Rats Fed on a Histidine Controlled Diet

\begin{tabular}{|c|c|c|c|c|}
\hline \multicolumn{2}{|c|}{ Diet } & $\begin{array}{l}\text { Weight gain } \\
\text { (g/week) }\end{array}$ & $\begin{array}{c}\text { Histidase } \\
\text { (mg urocanate/g liver } / \mathrm{hr} \text { ) }\end{array}$ & $\begin{array}{c}\text { GPT } \\
\text { (mg pyruvate/g liver } / \mathrm{hr} \text { ) }\end{array}$ \\
\hline Controlled & Histamin & $\begin{array}{l}7.1 \\
7.9\end{array}$ & $\begin{array}{l}0.40 \pm 0.10 \\
0.49 \pm 0.06\end{array}$ & $\begin{array}{l}90 \pm 7 \\
80 \pm 12\end{array}$ \\
\hline Imbalanced & - & 3.2 & $1.10 \pm 0.14$ & $250 \pm 33$ \\
\hline
\end{tabular}

Table III. EFfects of PZI on GRowth AND Histidase and GPT ACTIVIties OF RATS FED ON A HISTIDINE IMBALANCED DIET

\begin{tabular}{|c|c|c|c|}
\hline Diet & $\begin{array}{l}\text { Weight gain } \\
\text { (g/week) }\end{array}$ & $\begin{array}{c}\text { Histidase } \\
\text { (mg urocanate } / \mathrm{g} \text { liver } / \mathrm{hr} \text { ) }\end{array}$ & $\begin{array}{c}\text { GPT } \\
\text { (mg pyruvate } / \mathrm{g} \text { liver } / \mathrm{hr} \text { ) }\end{array}$ \\
\hline Imbalanced $\overline{\mathrm{PZI}}$ & $\begin{array}{r}-2 \\
16\end{array}$ & $\begin{array}{l}0.90 \pm 0.14 \\
0.85 \pm 0.05\end{array}$ & $\begin{array}{l}46 \pm 4 \\
37 \pm 18\end{array}$ \\
\hline
\end{tabular}


imbalanced diet but did not prevent the increase of histidase activity by the imbalanced diet (Table III), and decreased GPT activity a little. Triamcinolone injection caused severe loss of body weight, about $5 \mathrm{~g}$ per rat per day, and GPT increased more than 5 fold as much

TABLE IV. EFFECTS OF TRIAMCINOLONE INJECTION oN Weight Gain, Histidase and GPT ACtivities of Rats FED on Histidine CONTROLLED DiET

$\begin{array}{cccc}\begin{array}{c}\text { Triamcino- } \\ \text { lone }\end{array} & \begin{array}{c}\text { Weight } \\ \text { gain } \\ \text { (g/ } \\ \text { week) }\end{array} & \begin{array}{c}\text { Histidase } \\ \text { (mg urocanate/g } \\ \text { liver } / \mathrm{hr})\end{array} & \begin{array}{c}\text { GPT } \\ \text { (mg pyruvate/g } \\ \text { liver } / \mathrm{hr})\end{array} \\ - & 10 & 1.02 \pm 0.03 & 20 \\ 0.08 & -44 & 0.88 \pm 0.08 & >100 \\ 0.20 & -61 & 1.40 \pm 0.06 & >100\end{array}$

as that of the non treated control, but histidase did not show the obvious tendency (Table IV). Adrenalectomy was practically no effect on the activity of histidase contrasting to clear changes of GPT (Table V). Adrenaline did not affect on both enzymes.

\section{Effects of thyroxine and hypophysectomy}

In the previous experiment, ${ }^{31}$ thyroxine had been injected only once at the begining of the experiment and no change of enzyme activities was observed. In this experiment, rats were daily injected with thyroxine for two weeks. Food intake and weight gain of rats are shown in Fig. 1. Rats received thyroxine lost their body weight initially. The weight loss of rats

TAble V. EFfects of AdRenalectomy on Weight Gain, and Histidase and GPT ACtivities OF RATS FED ON EITHER Histidine CONTROLled OR IMBALANCEd DIET

$\begin{array}{lccc}\text { Diet } & \begin{array}{c}\text { Weight gain } \\ \text { (g/week) }\end{array} & \begin{array}{c}\text { Histidase } \\ \text { (mg urocanate/g liver/hr) }\end{array} & \begin{array}{c}\text { GPT } \\ \text { (mg pyruvate/g liver } / \mathrm{hr} \text { ) }\end{array} \\ \text { Adrenalectomy } & 12 & 0.45 \pm 0.05 & 73 \pm 10 \\ \text { - } & 4 & 0.43 \pm 0.05 & 26 \pm 5 \\ \text { Adrenalectomy } & 8 & 1.10 \pm 0.05 & 215 \pm 25 \\ & 5 & 1.02 \pm 0.10 & 62 \pm 5\end{array}$
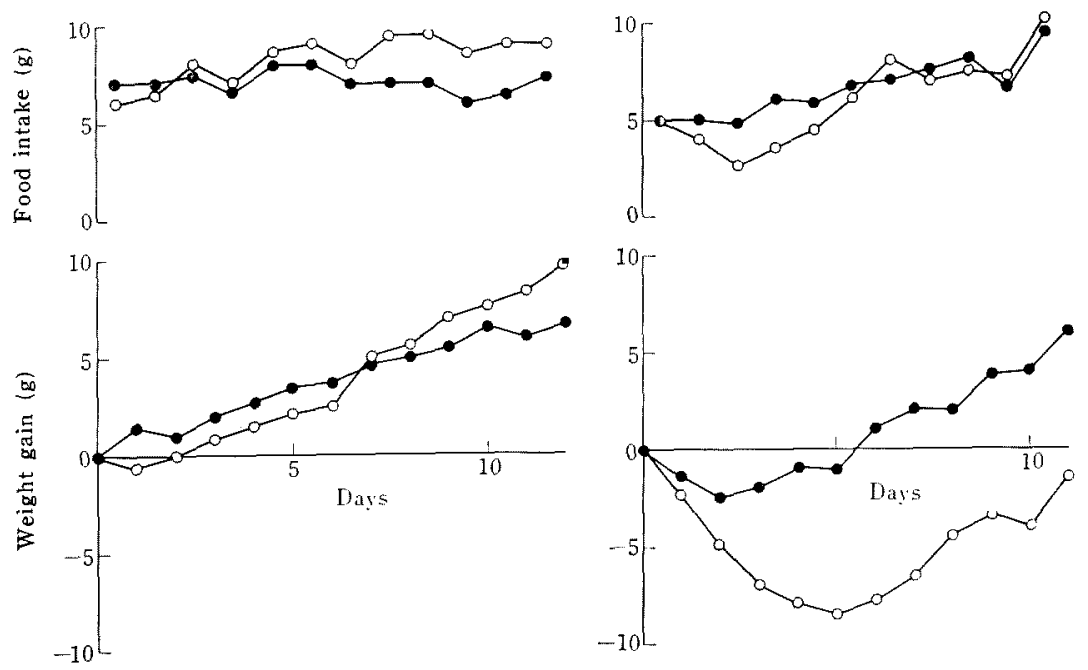

FIG. 1. Effects of Thyroxine $\left(\mathrm{T}_{4}\right)$ on Growth and Food Intake of Rats Fed on a Histidine Controlled or Imbalanced Diet.

$$
\begin{array}{ll}
\text {-O Controlled diet } \\
\text { O-O Controlled diet- } \mathrm{T}_{4}
\end{array}
$$

- Imbalanced diet O-O Imbalanced diet- $\mathrm{T}_{4}$ 
fed on the imbalanced diet continued till the 5 th day of the experiment and amounted to about $9 \mathrm{~g}$ by injection of deficient amount of thyroxine $(5 \mu \mathrm{g} / \mathrm{rat} / \mathrm{day})$, while the weight loss

TABLE VI. EFFECTS OF THYROXINE INJECTION ON Histidase aNd GPT ACTIVITIES OF RATS

Fed on EITHer Histidine Controlled OR IMBALANCED DIET

\begin{tabular}{|c|c|c|c|}
\hline \multicolumn{2}{|c|}{ Diet } & $\begin{array}{c}\text { Histidase } \\
\text { (mg urocanate/s } \\
\text { liver } / \mathrm{hr} \text { ) }\end{array}$ & $\begin{array}{c}\text { GPT } \\
\text { g (mg pyruvate/g } \\
\text { liver/hr) }\end{array}$ \\
\hline Controlled & Thyroxine & $\begin{array}{l}0.27 \pm 0.03 \\
0.11 \pm 0.02\end{array}$ & $\begin{array}{l}31 \pm 3 \\
29 \pm 3\end{array}$ \\
\hline Imbalanc & Thyroxine & $\begin{array}{l}0.85 \pm 0.10 \\
0.40 \pm 0.05\end{array}$ & $\begin{array}{l}66 \pm 1 \\
84 \pm 1\end{array}$ \\
\hline
\end{tabular}

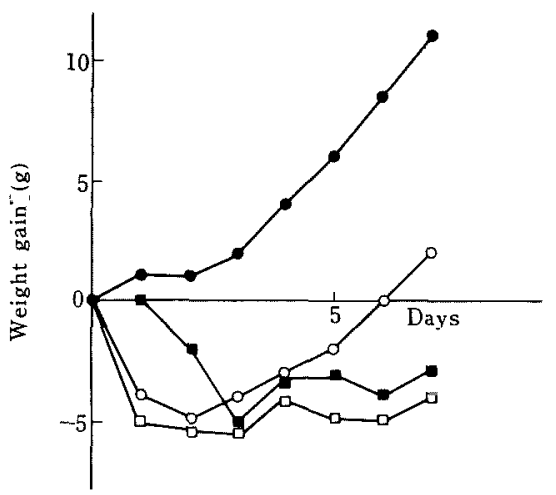

FIG. 2. Effect of Hypophysectomy on Growth of Rats.

- Controlled diet

O-O Imbalanced diet

-1 Controlled diet-hypophysectomy

Imbalanced diet-hypophysectomy of $10 \mu \mathrm{g} /$ day controlled group was $0.6 \mathrm{~g}$ only in the first day of the experiment. Initial loss of the body weight especially in the case of the imbalanced condition was related to diminished food intake, and the animals began to grow in response to the increase of food intake. The enzyme activities are shown in Table VI; histidase activity was depressed by the injection of thyroxine to a half of the non treated animals. GPT was not affected by the thyroxine. For the further investigation hypophysectomized animals were used for the dietary effects on the enzyme. The effects of operation on growth and enzyme activities were shown in Fig. 2 and Table VII. Growth curves of non treated group showed a typical response to the imbalanced diet, on the other hand, no growth was observed for the operated rats on either of the diets. Histidase activity increased about 4 fold as much as that of the non treated groups and GPT seemed not to be altered by the removal of hypophysis.

\section{DISCUSSION}

Auerbach et al. ${ }^{6)}$ reported that the injection of histidine did not elevate the activity of histidase. Decrease of the activity of histidase accompanied by the decrease of GPT by the administration of histidine, either orally or parenterally, to rats fed on histidine imbalanced diet might be due to the restoration of the balance of the amino acid pattern, the

Table VII. EFFects of Hypophysectomy on Histidase and GPT ACtivities of Rats Fed on Either Histidine CONTRolled or Imbalanced Diet

\begin{tabular}{|c|c|c|c|c|c|}
\hline & \multirow[b]{2}{*}{ Diet } & \multicolumn{2}{|c|}{ Exp. 1} & \multicolumn{2}{|c|}{ Exp. 2} \\
\hline & & $\begin{array}{c}\text { Histidase } \\
\text { (mg urocanate } / \mathrm{g} \\
\text { liver } / \mathrm{hr} \text { ) }\end{array}$ & $\begin{array}{c}\text { GPT } \\
\text { (mg pyruvate/g } \\
\text { liver/hr) }\end{array}$ & $\begin{array}{c}\text { Histidase } \\
\text { (mg urocanate/g } \\
\text { liver } / \mathrm{hr} \text { ) }\end{array}$ & $\begin{array}{c}\text { GPT } \\
(\text { mg pyruvate/g } \\
\text { liver } / \mathrm{hr} \text { ) }\end{array}$ \\
\hline Controlled & Hypophysectomy & $\begin{array}{l}1.00 \\
2.95\end{array}$ & $\begin{array}{l}14 \\
14\end{array}$ & $\begin{array}{l}0.65 \pm 0.05 \\
2.35 \pm 0.10\end{array}$ & $\begin{array}{l}24 \pm 2 \\
64 \pm 7\end{array}$ \\
\hline Imbalanced & Hypophysectomy & - & - & $\begin{array}{l}1.00 \pm 0.05 \\
3.80 \pm 0.75\end{array}$ & $\begin{array}{l}76 \pm 14 \\
76 \pm 4\end{array}$ \\
\hline
\end{tabular}

6) V.H. Auerbach and H. A. Waisman, Proc. Soc Expl. Biol. Med., 98, 123 (1958). 
decrease of stress, rather than specific action of histidine on histidase and GPT. The activities of histidase and GPT were independently varied by the dose of several hormones, e.g. histidase activity was decreased by thyroxine, while the activity GPT was decreased by PZI and increased by triamcinolone. But it is still a remaining problem whether the decrease of thyroxine and increase of corticoid hormone(s) were actually induced by feeding of the histidine imbalanced diet in the intact animals.

Histidase activity seems to be affected through hypophysis-thyroid gland route. Inhibitory effects of thyroxine on enzyme activities were reported in NAD-linked or $\mathrm{B}_{6}$ containing enzymes in vitro, ${ }^{7,8)}$ but histidase require neither NAD nor $B_{6}{ }^{9}{ }^{\prime \prime}$

Since hypophysectomy did not seem to affect the activity of GPT so much, the signal of corticoid secretion might directly work on

7) J. Wolff, J. Biol. Chem., 237, 230 (1962).

8) J. Wolff, ibid., 237, 236 (1962).

9) M. Takeuchi, J. Biochem. Japan, 34, 1 (1941). adrenal gland as the case mentioned by Munro, ${ }^{101}$ rather than the route via hypophysis, i.e. ACTH. However GPT activity of rats of adrenalectomy slightly increased by the imbalanced diet, therefore there might still be a possibility that diet affect on the enzyme through the route other than glucocorticoid.

Amino acid pattern in plasma was shifted to decrease of histidine ${ }^{111}$ and to increase of other amino acids ${ }^{12}$ by feeding the histidine imbalanced diet. Difference of amino acid pattern might lead to some metabolic change through the change of blood pattern of free amino acids.

It should be the problem solved hereafter what was the direct or primary target organ(s) for increase or decrease of enzyme activities responding to the change of amino acid pattern of the diets.

10) H. N. Munro, W. C. Hutchison, T.R. Ramaiah and F. J. Neilson, Brit. J. Nutri., 16, 387 (1962).

11) A. E. Harper, P. Lung, A. Yoshida and Q. R. Rogers, Fed. Proc., 23, 1087 (1964).

12) K. Noda and A. Yoshida, unpublished data. 